\title{
Council of Europe Preparing Treaty on Environmental Damage Compensation
}

An international treaty to improve, at the European level, compensation for damage caused by dangerous activities to the environment, persons, and property, will be prepared as soon as possible by the Council of Europe. East European States might also participate in such work.*

This initiative has recently been taken by the European Committee on Legal Cooperation (CDCJ) of the 23-nations' Organizations. There is an urgent need for such a treaty, because environmental accidents frequently affect several countries. This European treaty

* Already there was good news recently that Hungary is adhering to the Convention on the Conservation of European Wildlife and Natural Habitats, also called the 'Bern Convention', which provides for the protection of species in danger of disappearing, and indicates in particular 119 plant species and 400 species of fauna to be 'strictly protected'. -- Ed. will complement already-existing special treaties on environmental damage caused by transport, nuclear accidents, hazardous waste, and sea pollution.

The European Committee on Legal Cooperation is a Committee of Experts of the Council of Europe which assembles governmental experts of the 23 member States and prepares work in the field of legal cooperation. Currently these States are: Austria, Belgium, Cyprus, Denmark, Finland, France, Federal Republic of Germany, Greece, Iceland, Ireland, Italy, Liechtenstein, Luxembourg, Malta, Netherlands, Norway, Portugal, San Marino, Spain, Sweden, Switzerland, Turkey, and the United Kingdom.

INFORMATION DEPARTMENT
COuncil of Europe
BP 431 R6
F-67006 Strasbourg Cedex
France.

INFORMATION DEPARTMENT Council of Europe

F-67006 Strasbourg Cedex France.

\section{Tropical Timbers Solely from Sustainably-managed Sources by $1995 ?$}

At the meeting of the International Tropical Timbers Organization (ITTO) which was held during 13-23 May 1990 in Bali, Indonesia, WWF and other conservation INGOs pushed for the Organization to agree to the goal of a sustainable international tropical timber trade by the year 1995. This would mean that all tropical timber traded internationally would come from forests which are sustainably managed according to ITTO criteria. At the meeting, the ITTO agreed in principle with this goal, but set the target for the year AD 2000.

The WWF view is that we cannot afford to wait for 10 years. The urgency of the situation facing tropical forests was highlighted when an ITTO mission which had examined forest management in Sarawak, Malaysia, presented its findings. The mission reported that Sarawak, one of the world's major producers of tropical timber, will have logged all its primary forests outside protected areas within 11 years if present trends continue! After these primary forests have been logged, the productivity of logged-overforests is not expected to be sufficient to allow future harvests at anything like current levels.
Another development at the ITTO meeting was the adoption of operational guidelines for 'best practice' in tropical forest management. These guidelines are in the form of a check-list, and not only cover forestry techniques, but involve taking care also of biodiversity and social issues.

In principle, tropical forest countries will now develop national guidelines based on the ITTO ones, but which will be relevant for the particular conditions of their own forests.

The ITTO meeting was preceded by a 2-days' NGO seminar organized by WWF on community involvement in forest management. The ITTO is basically promoting industrial-scale forest management but neglecting other options, and WWF wants to draw attention to this. Examples were given from Irian Jaya, Thailand, Peru, Dominica, and Brazil.

CHRISTOPHER ELLIOTT, Senior Forests Officer
World-Wide Fund for Nature (WWF)
World Conservation Centre
Avenue du Mont-Blanc
1196 Gland, Switzerland.

CHRISTOPHER ElLIOTT, Senior Forests Officer

World Conservation Centre

1196 Gland, Switzerland.

\section{Destruction of the Tropical Rain-forests: How 'Green' is Brazil's New President?}

In November 1989, presidential elections were held in Brazil for the first time in 20 years. A good-looking young man, holder of the 'black belt' in karate, was elected as the country's chief executive. When, on March 15th of this year, the newly-elected Brazilian President, Fernando Collor de Mello, took office, one of his first official acts was to declare his commitment to the conservation of Brazil's environmental resources and the protection of the Amazon rain-forests. As a sign of goodwill, be nominated a leading Brazilian environmentalist, José Lutzenberger, as chief of the country's environmental agency. However, 1989 was also a record year in terms of the depredation of the Brazilian rain- forests, the dry spells being deliberately used by big farmers and landowners to increase the already astronomic proportions of the burning of the world's richest ecobiome. Estimates given by several international environmental organizations put the total loss at around 3 million hectares - an area which, combined with similar deforestation taking place elsewhere in Latin America, Western Africa, and South-east Asia, is approximately the size of Belgium.

Despite the nomination of Lutzenberger to head up Brazil's environmental agency, and the optimism with which the international community welcomed this initiative, President Mello faces two major challenges. The first is the 
desperate need for due rationalization in the use of the Amazon region's resources. To reach such a goal, it is necessary to strengthen the environmental laws and include higher penalties for those who burn more than a permissible area of forest that is found on their properties. In addition, a complete halt is urgently needed in the official support given to the immigration of workers from southern Brazil to the north - a process that has been taking place for more than a decade. These workers, attracted by offers of free land and by the richness of minerals in the area, exert strong pressures on the region's environment, being to some extent responsible for the burning of the Brazilian rain-forests.

The second major challenge faced by Brazil's new President is to ensure that the population of native 'indians' who inhabit the country's rain-forests are not destroyed either by the disappearance of their local environment (for example, by the building of dams), or by the white man's practices. Brazil's 'indian' population today is just over 200,000 , compared with the estimated 6 millions who were found by the Portuguese when they started to explore the country in the year 1500 . Over the past five years, a growing number of 'indians', from several Amazon tribes, have been killed in conflicts involving farmers and gold-diggers. The invasion of the "indians", territory for the exploitation of gold is a common practice in the region, and, not being armed or able to defend themselves, the 'indians' stand very little chance of survival.

The above problems are added to by an exacerbation of the country's economic difficulties which, in the past, were lightened by making use of the Amazon region's richness - especially of the rain-forests, which provided an easy source of hard cash. With the attention with which the international community now looks at developments in the region, such a soft choice is no longer tolerable. The fact that widespread destruction of rain-forests can lead to major ecological changes world-wide, implies that greater care than hitherto should in the future be taken in treating 'rain-forests-related issues'. Due to the amount and variety of pressures that are being placed on the country's forest ecosystems, the Brazilian President is under a test such as no head of state would wish to be submitted to.

The future will tell how 'green' is Brazil's new President, and how successful the policies which his government adopts in relation to the Brazilian rain-forests really are. Meanwhile the international scientific community has a major role to play: as in the past, when all of us were keen on pointing out mistakes, we should also support authentic progress and stimulate those who are really working for the reduction of the seriousness of one of today's major environmental problems.

Walter D.S. Leal Filho, Coordinator International Tropical Rain-forests Awareness Programme Institut für Erziehungswissenschaft Universität Hamburg Sedanstrasse 19 D-2000 Hamburg 1.3 Germany

\section{Institute for the Study of Natural Systems}

The Institute for the Study of Natural Systems is a nonprofit, tax-exempt, education and research organization which seeks to find new and innovative approaches to increasing harmony between people and Nature from a psychological standpoint. Current projects include:

1. The Spirit of Place Symposia: - Begun in 1988, this is a five-years' series of annual public symposia which bring together representatives of indigenous peoples to meet with modern designers, scientists', lawyers, and artists, to explore the nature of traditional Earth wisdom and its value to modern society's quest for finding ways to create sustainability. The first two programmes, held in 1988 at the University of California at Davis and in 1989 at Grace Cathedral in San Francisco, California, each featured 60 speakers. Proceedings from these presentations will be published by Quest Books in the spring of 1991 as a popular anthology, The Spirit of Place: Sacred Places and Spaces. Symposium co-producer James A. Swan, PhD, an environmental psychologist, also recently published Sacred Places: How The Living Earth Seeks Our Friendship (1990), which reflects on the spirit of place programme and 15 years' prior study of sacred space and its value to ancient and modern times.

The 1990 Spirit of Place symposium is being held at Mesa Verde National Park in Colorado, September 18-23, with many tribes of the Southwest sharing their traditional land heritage with park managers, architects, designers, and attorneys, in search of new ways to create sustainable cities and communities.

The 1991 Spirit of Place symposium will examine the peoples of the Pacific Rim, especially rain-forest cultures, and the 1992 programme will be held in Washington, DC, addressing public policy and urban design outcomes of the series of symposia.
2. 'Mr Recycleman' : - A recycling mascot to promote citizen participation in curbside recycling and litter-control programmes. The design for this loveable character comes from a county-wide children's art contest in Marin County, California, with the winning drawing by an eight-years'old boy. The actual character, who tours California at public events, was built by costume designers from Lucasfilm's award-winning 'Industrial Light and Magic'. A music video and musical comedy starring 'Mr Recycleman' are currently in preparation.

3. The Celebration for Mother Earth Concert: - A large public musical concert aimed at communicating mythic stories of traditional cultures in concert with popular musical treatments by well-known artists. The first concert was held at Grace Cathedral in San Francisco in August of 1989, featuring Steven Halpern and the undersigned, with members of 12 different Amerindian tribes recreating the creation myth of the Hopi Indian tribe. The second concert is slated for 14 December 1990 in San Francisco, featuring the music of Pete Sears' 'Watchfire' album which also features Jerry Garcia, Mickey Hart, Mimi Farina, Holly Nears, and yet others. This second programme will be a benefit performance for the Sioux Indian 'nation'.

Support for programmes of the Institute for the Study of Natural Systems has come from: The Beldon Fund, the JRH Foundation, Joshua Mailman, Laurance Rockefeller, The Skaggs Foundation, Lucasfilm Ltd, and Smith \& Hawken.

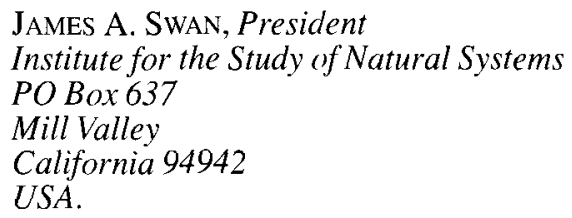

USA. 